\title{
Conventional and Real-Time PCR-Based Assay for Detecting Pathogenic Alternaria brassicae in Cruciferous Seed
}

\author{
Thomas Guillemette, UMR 77 Pathologie Végétale, Faculté des Sciences, Angers, France; Béatrice Iacomi- \\ Vasilescu, UMR 77 Pathologie Végétale, France, and USAMV, Department of Plant Protection, Bucharest, Romania; \\ and Philippe Simoneau, UMR 77 Pathologie Végétale, France
}

\begin{abstract}
Guillemette, T., Iacomi-Vasilescu, B., and Simoneau, P. 2004. Conventional and real-time PCRbased assay for detecting pathogenic Alternaria brassicae in cruciferous seed. Plant Dis. 88:490496.

Alternaria brassicae is an important seedborne pathogenic fungus responsible for the black spot disease of crucifers. Sanitary control of commercial seed is necessary to limit the spread of this pathogen. Current detection methods, based on culture and morphological identification of the fungus, are time consuming, laborious, and not always reliable. Therefore, a polymerase chain reaction (PCR)-based assay was developed with A. brassicae-specific primers designed on the basis of the sequence of two clustered genes potentially involved in pathogenicity. Two sets of primers were selected for conventional and real-time PCR, respectively. In both cases, A. brassicae was specifically detected using DNA extracted from seed. The real-time PCR-based method presented here can be automated easily and preliminary results indicate that it is efficient for quantitative estimation of seed infection.
\end{abstract}

Additional keywords: $\mathrm{ABC}$ transporter, molecular diagnostic, nonribosomal peptide synthase

The genus Alternaria comprises saprophytic and pathogenic species of filamentous fungi. Plant pathogens of this genus have a distinct and limited host range. It has been strongly suggested that both virulence and host specificity are partly dependent on the production of host-specific toxins (HSTs; 18,27). A complex of three species, A. brassicae, A. brassicicola, and A. japonica (formerly named A. raphani), is responsible for the black spot disease of crucifers and is transmitted by seed of many species belonging to the genera Brassica and Raphanus. The disease is of major importance in cultivated crucifers worldwide, with most commercial cultivars being susceptible (25). It occurs at all host plant growth stages, on aerial parts, and is identifiable by black lesions, often surrounded by chlorotic zones (26). The disease also can be destructive for seed producers because infection often leads to premature pod shatter and shriveled seed, with altered germination efficiency, as noted in various crucifer hosts such as Brassica juncea, B. campestris, and $B$. rapa $(20,21)$. Black spot disease results in

Corresponding author: P. Simoneau

E-mail: simoneau@univ-angers.fr

This work was supported by a Contrat de Plan EtatRégion Pays de Loire (2000-2003).

Accepted for publication 19 December 2003.

Publication no. D-2004-0301-01R

(C) 2004 The American Phytopathological Society a serious reduction of crop yields, such as reduced market quality of cauliflower heads and oil quality in family Brassicaceae oilseed species. The fungi overwinter on infected crop residues, seed, and any related cruciferous weed species. They can be seedborne via mycelia within the seed or transitory spores on the seed surface. Spores are readily windborne and can be dispersed great distances throughout the growing season.

Common practices to prevent the disease do not always provide satisfactory control of infection. Genetic control could be the most effective strategy, but most commercially available cultivars show little resistance to the pathogen. Black spot disease could be controlled with fungicides, but field isolates of $A$. brassicicola expressing cross-resistance to common broad-spectrum fungicides recently were identified in France (7). Rotations with noncruciferous crops, crop residue destruction, and weed control also can help to reduce the incidence of this disease. Moreover, the use of pathogen-free seed is essential to limit the spread and incidence of the disease. The current routine technique used to assess levels of pathogenic Alternaria spp. contamination in cruciferous seed is based on the culture of the seedborne fungi on nutritive media and further morphological characterization. This is a time-consuming process, whereby it takes at least 1 week to obtain a diagnostic result. Accurate diagnosis is not easy because numerous saprophytic Alternaria spp. commonly are found on cruciferous seed (1), thus complicating pathogen identification. Some isolates sporulate sparsely or produce sterile mycelium under laboratory conditions. Morphological identification is impossible when this occurs.

Molecular approaches, mainly the polymerase chain reaction (PCR), frequently have been used as tools for the detection of numerous fungal pathogens $(4,14,17)$. A sensitive and rapid PCR assay, based on amplification of sequences of the internal transcribed spacer (ITS) regions of the ribosomal DNA, recently was developed to detect $A$. brassicicola or A. japonica infection of cruciferous seed (8). Unfortunately, this method did not generate a reliable diagnosis when seed were contaminated with A. brassicae because cross-reactions with other fungal species sometimes were observed.

Johnson et al. (10) recently described the use of a PCR-based technique using primers designed from a gene involved in pathogenicity (synthesis of the host-specific AM-toxin) to specifically $\operatorname{detect} A$. alternata apple pathotypes among Alternaria field isolates. Host specificity-typical of several pathogenic Alternaria spp.is dependent mainly on toxin production; therefore, effective molecular probes could be developed for diagnostic techniques by cloning genes involved in virulence.

In the present study, we developed PCR assays for detecting A. brassicae in seed batches. These methods used oligonucleotides complementary to sequences located on a cluster of genes that may be required for the pathogenicity of the fungus. The specificity and suitability of the designed primers were tested using standard and real-time PCR.

\section{MATERIALS AND METHODS}

Fungal strains and culture conditions. Isolates of Alternaria spp. and other genera (Table 1) were recovered from seed. Cultures were grown and maintained in petri dishes on potato dextrose agar. Alternaria isolates were identified on the basis of morphology criteria $(11,16)$. Identifications then were confirmed by PCR using specific ITS primer pairs (8) for Alternaria spp. pathogenic to crucifers.

Preparation of seed samples. Seed samples were prepared from contaminated seed of radish and cabbage as described by Iacomi-Vasilescu et al. (8). For artificial contaminations, seed were disinfected with 
$1 \%$ sodium hypochlorite, rinsed with sterile water, soaked for $1 \mathrm{~h}$ in a calibrated spore suspension $\left(10^{6}\right.$ spores $\left./ \mathrm{ml}\right)$, and dried at room temperature on sterile filter paper. Disinfection and inoculation accuracy was confirmed by placing 20 seed on the surface of malt-agar plates for 1 week at $25^{\circ} \mathrm{C}$. Seed batches showing $0 \%$ (disinfected seed) or $100 \%$ (inoculated seed) infection were selected and mixed together to prepare seed samples with different levels of contamination $(0,5,10,50$, and $100 \%)$. Samples were produced by placing 20 seed (artificially contaminated) or 100 seed (naturally contaminated) in a sterile tube and covering them with 0.5 and $3 \mathrm{ml}$, respectively, of liquid culture MDP medium ( $2 \%$ malt extract, $2 \%$ dextrose, $0.1 \%$ peptone). The tubes were incubated at $25^{\circ} \mathrm{C}$ for $48 \mathrm{~h}$ with occasional shaking. This incubation step is an enrichment phase that allows an optimal increase of the fungal biomass from seed. The tubes then were vortexed briefly to separate mycelia and conidia from seed. The seed were discarded and the fungal structures were collected on microcentrifuge filters (pore size: $0.45 \mu \mathrm{m}$; Ultrafree-Mc Millipore, Bedford, MA) by centrifugation at $5,000 \times g$ for $10 \mathrm{~min}$.
DNA manipulation. DNA was extracted from fungal mycelia and conidia harvested by scraping the surface of petri plate cultures (extraction from fungal cultures) or collected on microcentrifuge filters (extraction from seed samples). Nucleic acids were isolated according to the microwave miniprep procedure described by Goodwin and Lee (6). Alternatively, DNA was extracted using the $\mathrm{Nu}$ cleospin Food kit (Macherey-Nagel, Düren, Germany) according to the manufacturer's instructions.

PCR-based assay. Specific oligonucleotides ABCsens (5'-CTGGTGAAAAGGTTGCGATCGT-3') and ABCrev (5'GTGACTTTCATGAAATGACATTGATG$3^{\prime}$ ), complementary to the $3^{\prime}$ end of open reading frame $(\mathrm{ORF}) 2$, and 115 sens $\left(5^{\prime}\right.$ AACCCTATAGACCCACGTCGACTA- $3^{\prime}$ ) and 115rev (5'-GATGGTACGCAAGGCTTGGT-3'), complementary to a portion of ORF1, were designed for the standard and real-time PCR assays, respectively, using the appropriate software (Primer 3 online and ABI PRISM Primer Express). The two ORFs were deduced from the nucleotide sequence of an A. brassicae genomic DNA fragment identified after screening a cos- mid library with a probe corresponding to a portion of the nonribosomal peptide synthase (NRPS) gene. In order to test the specificity of the primer pairs against $A$. brassicae isolates, amplifications were performed using DNA extracted from pure fungal cultures from a range of Alternaria spp. and other fungi isolated from seed. Then the PCR procedure was applied to detect seed contamination. The universal primer pair ITS1/ITS2 (28) was used as a positive control to assess the quality of the extracted DNA. Conventional PCR was performed using $2 \mu \mathrm{l}$ of undiluted DNA preparations under the following conditions: Tris- $\mathrm{HCl}, \quad \mathrm{pH} 9.0, \quad 20 \mathrm{mM}$ $\left(\mathrm{NH}_{4}\right)_{2} \mathrm{SO}_{4}, 0.01 \%$ (wt/vol) Tween 20, 1.5 $\mathrm{mM} \mathrm{MgCl} 2,200 \mu \mathrm{M}$ each deoxyribonucleotide triphosphate, and 1 unit of thermostable DNA polymerase (Goldstar Red DNA polymerase, Eurogentec, Seraing, Belgium). A Thermojet thermocycler (Equibio, Seraing, Belgium) was used with an initial step of $3 \mathrm{~min}$ at $95^{\circ} \mathrm{C}$; followed by 35 cycles of $30 \mathrm{~s}$ at $95^{\circ} \mathrm{C}, 50 \mathrm{~s}$ at $60^{\circ} \mathrm{C}$, and $1 \mathrm{~min}$ at $72^{\circ} \mathrm{C}$; and a final step of 10 $\min$ at $72^{\circ} \mathrm{C}$. The amplification results were visualized after electrophoresis of an aliquot $(10 \mu \mathrm{l})$ of the reaction mixture on a

\section{DNA extracted from:}

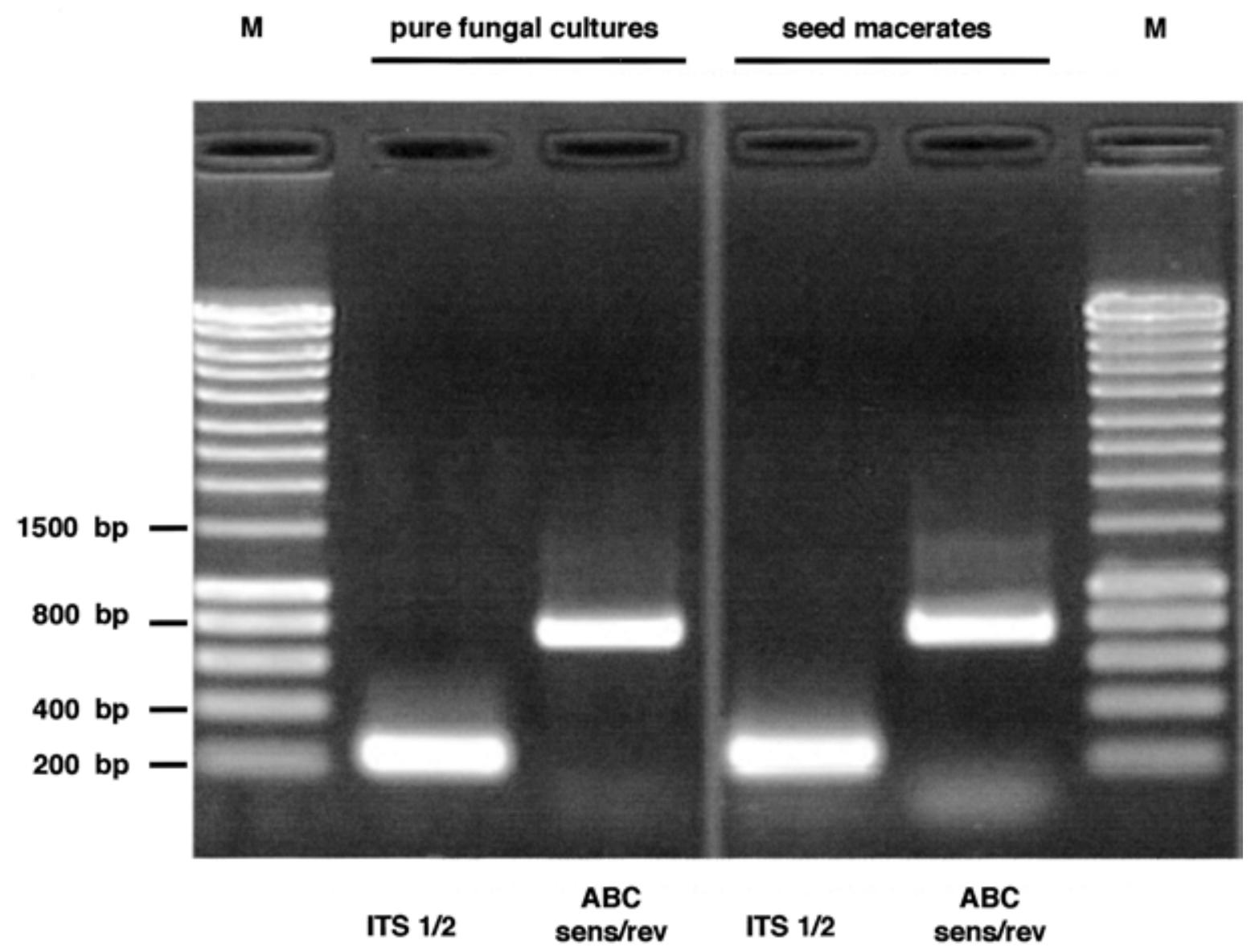

Fig. 1. Gel electrophoresis of polymerase chain reaction products obtained with internal transcribed spacer (ITS) $1 / 2$ universal primers and with ABCsens/rev diagnostic primers. DNA was extracted from pure Alternaria brassicae cultures or from radish seed infected with A. brassicae, using the Nucleospin Food kit. Lanes M were loaded with a DNA ladder (SmartLadder Classic, Eurogentec, Seraing, Belgium). 
$1.2 \%$ agarose gel. The real-time PCR reactions were carried out in a $25-\mu$ final volume containing: $2.5 \mu \mathrm{l}$ of DNA, $12.5 \mu \mathrm{l}$ of SYBR Green PCR Master Mix 2X (Applied Biosystems, Courtaboeuf, France), $300 \mathrm{nM}$ forward and reverse primers and $\mathrm{H}_{2} \mathrm{O}$ up to $25 \mu \mathrm{l}$. An ABI PRISM $700 \mathrm{Se}-$ quence Detection System (Applied Biosystems) was used with the following steps: 2 $\min$ at $50^{\circ} \mathrm{C}, 10 \mathrm{~min}$ at $95^{\circ} \mathrm{C}$, and $40 \mathrm{cy}-$ cles consisting in one step at $95^{\circ} \mathrm{C}$ for $15 \mathrm{~s}$ followed by one step at $60^{\circ} \mathrm{C}$ for $1 \mathrm{~min}$. Nucleic acids were quantified in unknown samples by direct comparison to a standard. The DNA used as standard was extracted from fungal cultures, with the concentration measured by fluorometric assay (Turner Design Inst. 700, Sunnyvale, CA) before dilution.

\section{RESULTS}

Selection of the diagnostic PCR primers. Bacterial and fungal genes involved in toxin production have been used successfully to develop molecular diagnostic tools (10). Therefore, primer pairs were designed on the basis of the nucleotide sequence of a potential pathogenic cluster of two A. brassicae genes encoding an NRPS and an ATP-binding cassette (ABC) transporter. These genes putatively are involved in the synthesis and excretion of a toxic peptide metabolite produced by A. brassicae and, thus, may be suitable targets for PCR-based detection of this pathogen. We expected to find homologous genes in related pathogenic Alternaria spp; therefore, PCR screening of the A. japonica and $A$. brassicicola genomes was performed using primers that span the A. brassicae gene cluster. This preliminary approach revealed that the two A. brassicae ORFs have counterparts on the genome of other Alternaria spp. pathogenic to crucifers (data not shown). However, the central part and 3' end of the NRPS and ABC transporter, respectively, were found to be less conserved among the three species. Therefore, we focused on these regions to select primers for specific detection of A. brassicae. Two primer pairs were designed: one for standard PCR assays, called ABCsens/ABCrev, located near the $3^{\prime}$ end of the ABC transporter gene coding sequence; and one for real-time PCR assays, called 115 sens/115rev, located at approximately $10 \mathrm{~kb}$ of the NRPS gene start codon.

DNA extraction from seed. DNA was extracted routinely from fungal mycelia in pure cultures or from seed samples using a standard miniprep procedure. This technique involved lysis at high temperature in a detergent-containing buffer, extraction with organic solvents, and nucleic acid precipitation in the presence of alcohol. However, alternative extraction procedures using commercial kits were tested with the aim of designing a simple and safe diagnostic assay that could be automated to

Table 1. Names and origins of species and isolates used in the present study

\begin{tabular}{|c|c|c|c|c|}
\hline \multirow[b]{2}{*}{ Species } & \multirow[b]{2}{*}{ Isolate no. } & \multirow[b]{2}{*}{ Origin } & \multicolumn{2}{|c|}{ Detection by } \\
\hline & & & conv-PCR ${ }^{\mathrm{a}}$ & Q-PCR ${ }^{b}$ \\
\hline Alternaria brassicae & Bre14 & Radish seed & + & + \\
\hline A. brassicae & Bre16 & Radish seed & + & + \\
\hline A. brassicae & Bre39 & Radish seed & + & + \\
\hline A. brassicae & Bre103 & Radish seed & + & + \\
\hline A. brassicae & Bre112 & Radish seed & + & + \\
\hline A. brassicicola & $\mathrm{Bra3}$ & Radish seed & - & - \\
\hline A. brassicicola & Bra18 & Radish seed & - & - \\
\hline A. brassicicola & Bra40 & Radish seed & - & - \\
\hline A. brassicicola & Bra41 & Radish seed & _- & - \\
\hline A. brassicicola & Bra43 & Radish seed & - & - \\
\hline A. japonica & Jap4 & Radish seed & - & - \\
\hline A. japonica & Jap19 & Radish seed & - & - \\
\hline A. japonica & Jap52 & Radish seed & - & - \\
\hline A. japonica & Jap63 & Radish seed & - & - \\
\hline A. japonica & Jap108 & Radish seed & - & - \\
\hline A. alternata & Alt62 & Radish seed & - & - \\
\hline A. alternata & R7404 & Cabbage seed & - & - \\
\hline A. dauci & R9228 & Cress seed & - & nt \\
\hline Ulocladium chartarum & Ulo75 & Radish seed & - & - \\
\hline Stemphylium botryosum & C27381 & Cabbage seed & - & - \\
\hline S. botryosum & R7410 & Cabbage seed & - & _- \\
\hline Botrytis cinerea & BC40 & Sunflower seed & - & nt \\
\hline Fusarium sp. & Fu6 & Radish seed & _- & - \\
\hline Fusarium sp. & Fu7 & Radish seed & - & - \\
\hline Phoma sp. & Pho1 & Radish seed & - & - \\
\hline Penicillium sp. & P1 & Cabbage seed & - & - \\
\hline Aspergillus sp. & $\mathrm{A} 2$ & Cabbage seed & - & - \\
\hline Verticillium sp. & $\mathrm{V} 1$ & Tomato seed & - & nt \\
\hline
\end{tabular}

a conv-PCR refers to conventional polymerase chain reaction (PCR) with the ABCsens-ABCrev primer set.

b Q-PCR refers to real-time PCR with the 115 sens-115rev primer set; + = amplification, $-=$ no amplification, and $\mathrm{nt}=$ not tested. process numerous samples. The Nucleospin Food kit was found to be the most efficient. Irrespective of the method used for isolating nucleic acids (i.e., from pure fungal cultures or seed samples), similar amplification patterns were obtained with both universal and specific primer pairs (Fig. 1). The DNA obtained with the Nucleospin Food kit also was tested successfully as template for real-time PCR (described below).

Specificity of the selected PCR primers. To test the specificity toward A. brassicae isolates, $\mathrm{ABCsens} / \mathrm{rev}$ primers were first used in a PCR reaction with genomic DNA extracted from mycelial pure cultures of different fungal isolates (Table 1). These were selected to represent a range of fungi commonly found on cruciferous seed, including the three pathogenic Alternaria spp. A. brassicicola (five isolates), A. japonica (five isolates), and A. brassicae (five isolates), as well as saprophytic $A$. alternata isolates (two isolates), and isolates of Fusarium spp. (two isolates), Penicillium spp., Aspergillus spp., and Phoma spp. (one isolate each). Another seedborne Alternaria sp. (A. dauci) and isolates from the closely related genera Ulocladium and Stemphylium also were tested, along with one Botrytis cinerea strain isolated from sunflower seeds. A representative sample gel is shown in Figure 2. After optimisation of the cycling parameters, PCR products of the expected size $(780 \mathrm{bp})$ were obtained from $A$. brassicae isolates only. No cross hybridization was observed with other cruciferous pathogenic Alternaria spp. (A. brassicicola or A. japonica; Fig. $2 \mathrm{~A}$ and $2 \mathrm{~B}$ ), with nonpathogenic A. alternata or other tested fungi (Fig. 2C). Signals were obtained with all tested fungi when the universal ITS1-ITS2 primer pair was used as a control of DNA quality (data not shown).

The specificity of the real-time PCR primers was checked using 100 pg of DNA extracted from pure cultures of fungi listed in Table 1. All of the selected fungi originated from cruciferous seed. No increasing fluorescent signal exceeding the background fluorescence (baseline threshold) was observed except when $A$. brassicae DNA was used as template. In that case, standard fluorescent amplification curves representing an exponential growth of PCR products were recorded and a mean 26.65 threshold cycle $\left(\mathrm{C}_{\mathrm{T}}\right)$ was obtained. Melting temperature profiles of the PCR products at the end of the cycling reactions were determined with samples containing $A$. brassicae DNA. A single dissociation peak of increased fluorescence was obtained for the specific 115 sens-115rev primer at a melting temperature of 83 to $84^{\circ} \mathrm{C}$ (data not shown). This indicated that the specific amplification obtained did not involve cross hybridization with other A. brassicae-related sequences or the formation of primer dimers. 
PCR detection in seed samples. In a preliminary experiment, the PCR detection test was applied to radish and cabbage seed batches artificially contaminated with A. brassicae (isolate Bre112). DNA was extracted from the different seed samples and used as a template in PCR experiments with either the ABCsens-ABCrev primer pair (standard assays) or the 115sens115 rev primer pair (real-time PCR). In the latter case, parallel experiments with serial dilutions of a calibrated $A$. brassicae DNA extract were carried out. A. brassicae was detected using the conventional PCR procedure in all contaminated seed batches (Fig. 3), even at contamination levels as low as 5\% (Fig. 3B). As expected, a signal also was observed with the positive control (DNA extracted from a mycelial pure culture of the A. brassicae isolate) but not with the negative control (disinfected seed). Amplifications using the universal ITS1/ITS2 primer pair were successful with all samples, indicating that the extracted DNA was suitable for PCR (Fig. 3A). No fungal growth was observed with disinfected seed plated on solid growth medium; therefore, the signal obtained with these seed after amplification with the nonspecific primers probably originated from co-extracted host plant DNA.

When real-time PCR was used with serial dilutions of an A. brassicae DNA calibrated extract as template, a standard curve was plotted using known amounts of $A$. brassicae DNA against the $\mathrm{C}_{\mathrm{T}}$ calculated with ABI Prism 7000 sequence detection system (SDS) software (Fig. 4). This curve revealed that the primer set used in this experiment was quite accurate over a linear range of at least 3.5 orders of magnitude and that the correlations between $\mathrm{C}_{\mathrm{T}}$ and DNA quantities were high $\left(R^{2}=0.986\right)$. The mean $\mathrm{C}_{\mathrm{T}}$ values obtained with 100 and $10 \%$ artificially contaminated radish seed batches were 25.56 and 32.55 , respectively, corresponding to approximately 250 and $3.5 \mathrm{pg}$ of $A$. brassicae DNA, respectively.

These results were obtained with artificially contaminated seed free of other fungal or bacterial contaminations. It was then necessary to check this molecular diagnosis approach with cabbage and radish seed naturally contaminated with pathogenic Alternaria spp. Six different seed lots were tested (Table 2). Infection levels were determined on 200 seed using the standard plating technique. Amplifications using the nonspecific ITS1-ITS2 primer pair were successful with all DNA extracted from samples, indicating that this DNA was suitable for further amplifications (Fig. $5 \mathrm{~B})$. When the $\mathrm{ABCsens} / \mathrm{rev}$ primer pair was used, A. brassicae contaminations up to $3 \%$ (seed lot D) were detected (Fig. 5A). No amplification signal was obtained with DNA extracted from the A, B, and C seed lots.
Real-time PCR was carried out with samples prepared with the six radish seed lots. Amplification curves were obtained only with DNA extracted from lots $\mathrm{C}$ to $\mathrm{F}$. Similar $\mathrm{C}_{\mathrm{T}}$ values (mean: 32.54) were noted for seed lots $\mathrm{E}$ and $\mathrm{F}$ (Fig. 4). This mean value is close to that obtained with the $10 \%$ artificially contaminated seed batch. The $\mathrm{C}_{\mathrm{T}}$ value for seed lot $\mathrm{C}$, with an A. brassicae infection level of $2 \%$, was 34.28 .

\section{DISCUSSION}

Conventional tests used to detect $A$. brassicae in seed involve a combination of pathogenicity assays and morphological characterization. However, the drawback of such methods is that accurate pathogen identification can be difficult and timeconsuming. Hence, there is an urgent need for a sensitive and rapid test that could detect seedborne A. brassicae. With advances in molecular biology, most recently developed techniques for microorganism detection involve PCR analysis. The advantages of PCR-based assays include specificity, sensitivity, and speed. Hence, such assays have been designed for the detection of various plant pathogens, including seedborne fungi $(22,24)$. A few PCR-based methods have already been reported for the detection of Alternaria spp. on carrot $(12,19)$, linseed (15), and cruciferous (8) seed, as well as in host tissues (15) or food products (32). The ITS region of nuclear $\operatorname{rDNA}(8,12,15,32)$ is the main genomic region targeted for PCR primer development. Recently, IacomiVasilescu et al. (8) reported a sensitive and rapid PCR diagnostic assay for the identification of A. brassicicola and A. japonica on cruciferous seed. Nevertheless, the ITS
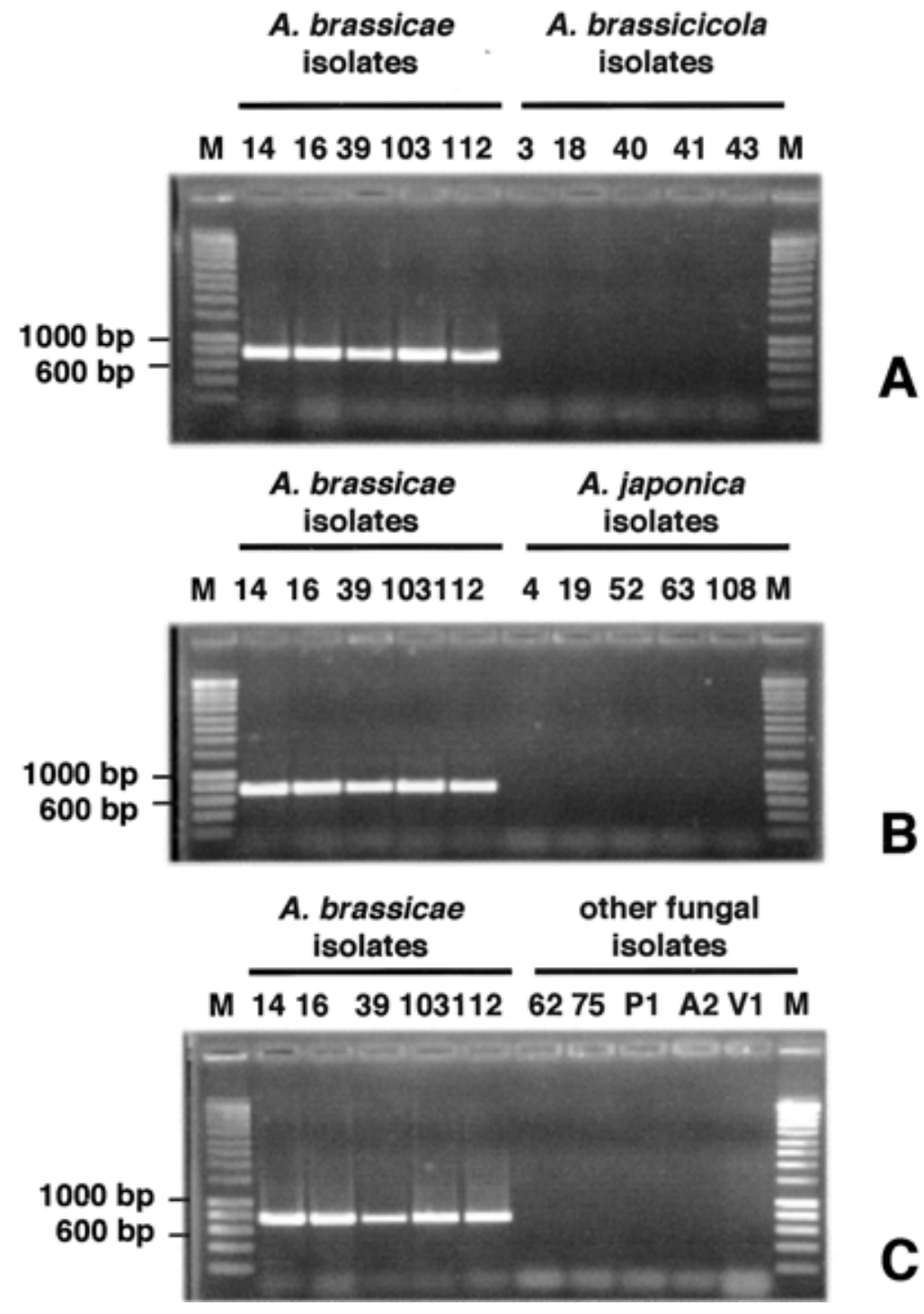

Fig. 2. Gel electrophoresis of polymerase chain reaction products obtained with the ABCsens/rev diagnostic primers and DNA extracted from pure cultures of various Alternaria brassicae isolates or from pure cultures of $\mathbf{A}$, A. brassicicola isolates or $\mathbf{B}$, A. japonica isolates or $\mathbf{C}$, isolates from different fungal species recovered from seed. Numbers above the gels correspond to isolate identification codes as described in Table 1. M lanes were loaded with a DNA ladder (SmartLadder Classic, Eurogentec, Belgium). 
primers designed in this study for A. brassicae were found to be not very specific because amplification signals were consistently obtained with DNA from some $A$. japonica isolates.

In the present study, we used two primer sets, highly specific to A. brassicae, designed from two clustered genes corresponding to an NRPS gene and an ABC transporter gene. These two genes may produce and secrete factors associated with the virulence of the fungal pathogen (i.e., host-specific peptidic toxins or siderophores).

The conventional PCR-based seed assay that we developed specifically detects the presence of $A$. brassicae in cruciferous seed, even at infection levels as low as 3\% and after only 2 days of incubation. The first major obstacle that we had to overcome was the low levels of target DNA from the fungi. An incubation of $48 \mathrm{~h}$ in MDP liquid nutritive medium was suitable to obtain an optimal increase of the fungal biomass (8); therefore, the amount of fungal genomic DNA recovered generally was sufficient for amplification of the target

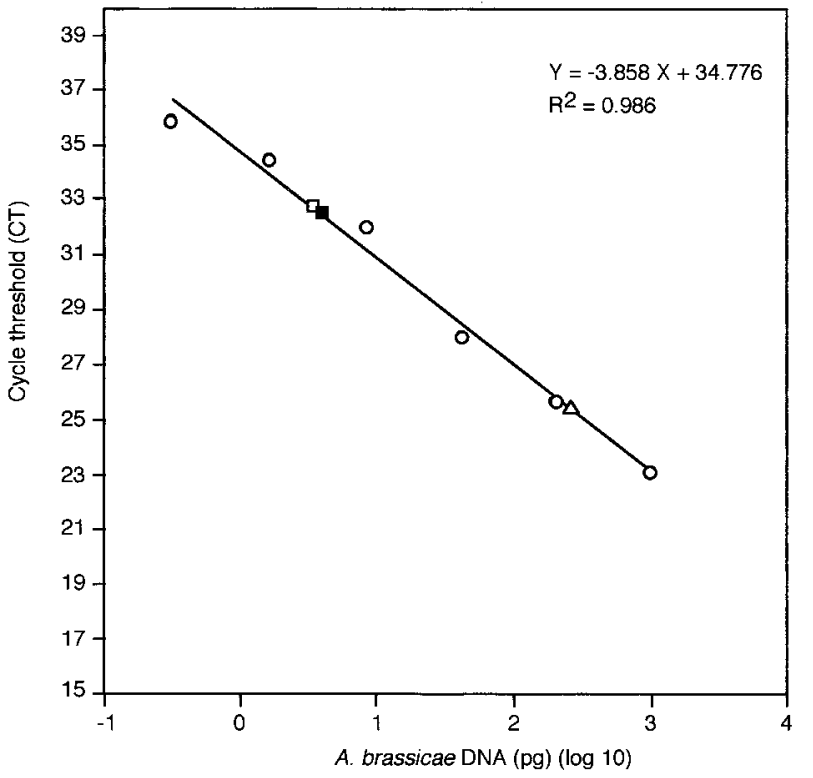

Fig. 4. Standard curve of Alternaria brassicae DNA concentration standards against the cycle threshold $\left(\mathrm{C}_{\mathrm{T}}\right) . \mathrm{C}_{\mathrm{T}} \mathrm{s}$ were determined, using real-time PCR and $115 \mathrm{sens} / \mathrm{rev}$ diagnostic primers, as the cycle at which the fluorescent signal exceeded background fluorescence. $\mathrm{C}_{\mathrm{T}} \mathrm{s}$ obtained with DNA extracted from $100 \%(\Delta)$ and $10 \%(\square)$ artificially contaminated radish seed or $10 \%$ naturally infected radish seed $(\mathbf{\square})$ are indicated on the plot.

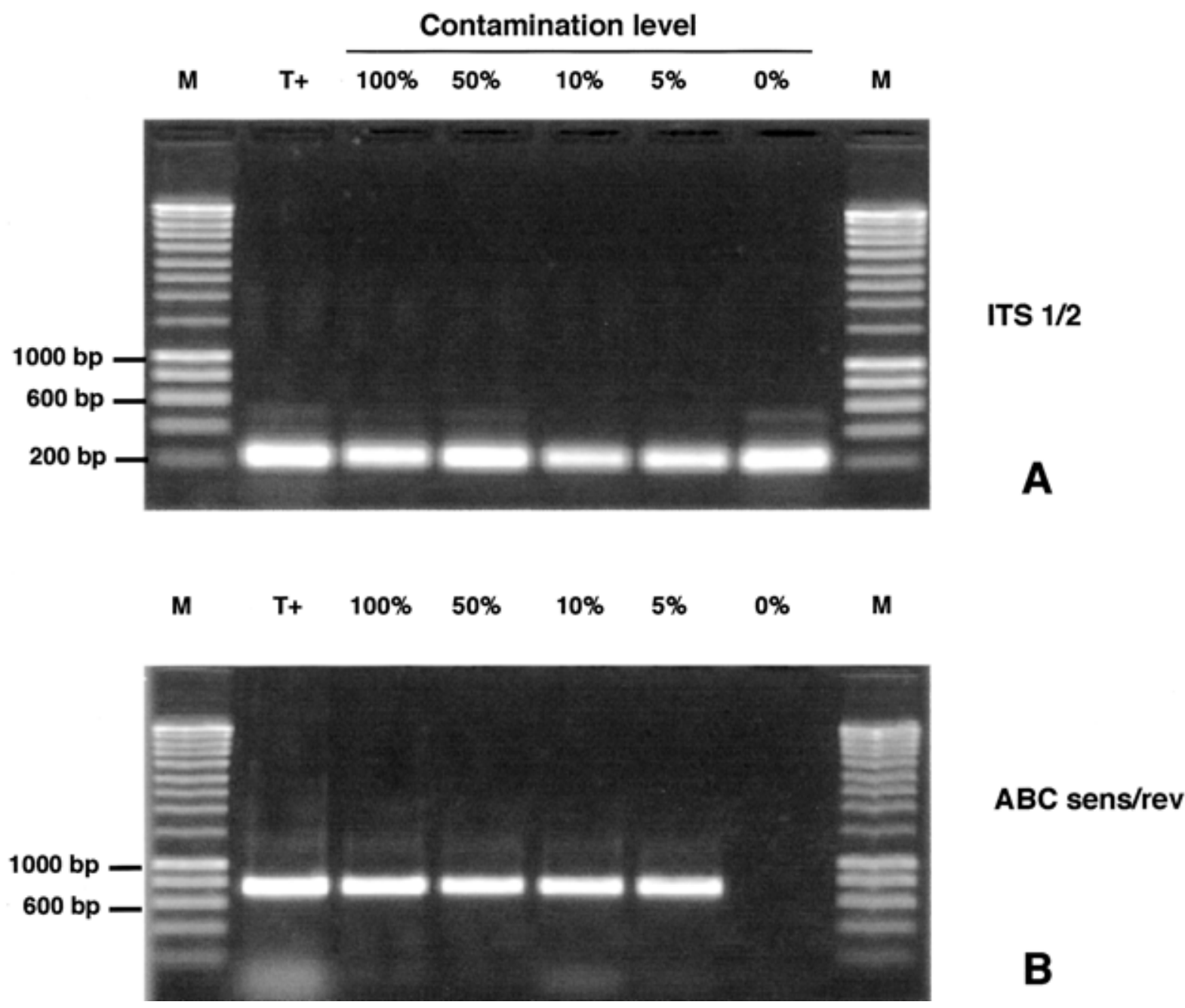

Fig. 3. Gel electrophoresis of polymerase chain reaction products obtained with internal transcribed spacer (ITS) $1 / 2$ universal primers or ABCsens/rev diagnostic primers and DNA extracted from seed artificially infected with Alternaria brassicae. Seed contamination levels are indicated above the gels. Lanes labeled T+ were loaded with DNA extracted from a pure culture of A. brassicae and lanes labeled M were loaded with a DNA ladder (SmartLadder Classic, Eurogentec, Seraing, Belgium). 
DNA sequences. The nutritive medium used for macerating seed was chosen on the basis of our previous observations. Two other liquid incubation media (i.e., clarified V8 broth and $\mathrm{CW}$; 30), also were tested by Iacomi-Vasilescu et al. (8). Similar results were obtained with MDP or V8 media, but MDP was preferred because of easier handling during a subsequent filtration step, whereas no signal was obtained with the $\mathrm{CW}$ medium. PCR inhibitors represent another obstacle commonly encountered when conducting assays using complex samples $(3,9)$. These inhibitors often have seed component origins (19). In this study, the seed were removed after incubation and prior to DNA extraction and fungal mycelia and conidia were collected using a spin filter unit. For technical reasons (e.g., size of the spin filter), we used seed batches containing only 100 seed. Thus, infection levels lower than $3 \%$ were not detected with good repeatability. In the original PCR diagnostic method described for A. japonica and A. brassicicola (8), phenol-chloroform extraction followed by an isopropanol precipitation step were sufficient to obtain a crude DNA preparation that subsequently could be used as template for amplification without any further treatment. In the present work, we demonstrated that this DNA isolation procedure could be replaced successfully

Table 2. Infection level (\%) of seed lots naturally infected with pathogenic Alternaria spp. used in the present study

\begin{tabular}{|c|c|c|c|c|c|c|}
\hline \multirow[b]{2}{*}{ Fungal species } & \multicolumn{6}{|c|}{ Infection level (\%) of seed lot number } \\
\hline & A (cabbage) & B (radish) & $\mathrm{C}$ (radish) & D (radish) & E (radish) & F (radish) \\
\hline Alternaria brassicae & 0 & 0 & 2 & 3 & 9.5 & 10 \\
\hline A. brassicicola & 8 & 0 & 0 & 0 & 0 & 0 \\
\hline A. japonica & 0 & 1 & 0 & 0 & 0 & 0 \\
\hline A. alternata & 19 & 39 & 11 & 38.5 & 27 & 13.5 \\
\hline Fusarium sp. & 2 & 0 & 0 & 1 & 0 & 0.5 \\
\hline Phoma sp. & 1 & 0 & 0 & 1.5 & 0 & 0 \\
\hline
\end{tabular}

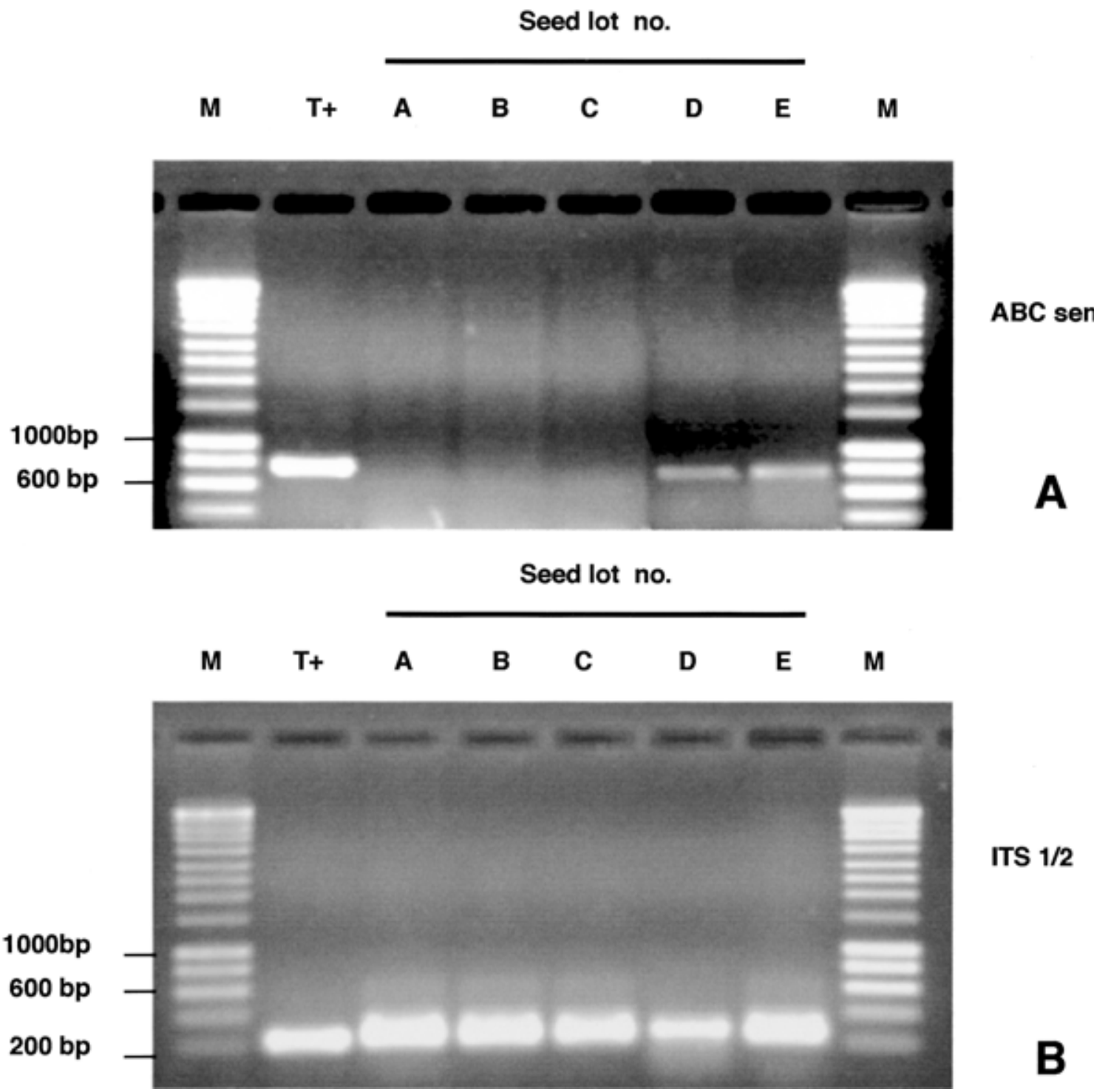

Fig. 5. Gel electrophoresis of polymerase chain reaction products obtained with $\mathbf{A}$, ABCsens/rev diagnostic primers or $\mathbf{B}$, internal transcribed spacer (ITS) $1 / 2$ universal primers and DNA extracted from seed. Samples were prepared with seed naturally infected with Alternaria spp. from seed lots A to E. Lanes labeled T+ were loaded with DNA extracted from a pure culture of Alternaria brassicae and lanes labeled M were loaded with a DNA ladder (SmartLadder Classic, Eurogentec, Seraing, Belgium). 
by treating the fungal mycelium with a lysis buffer initially designed for processing food samples, and purifying DNA using an affinity-based method with silica membranes from a commercial kit. This DNA extraction procedure potentially could be used for routine analysis of seed lots and is amenable to automation. In the same vein, routine analyses require an alternative method for electrophoretic separation of the amplification products. Our preliminary results with real-time PCR using SYBR green are encouraging. This fluorescent reporter dye binds doublestranded DNA; therefore, increasing fluorescence may be monitored continuously during the amplification procedure, thus eliminating the need for post-PCR analysis. Real-time PCR assays have been implemented for the detection of fungal plant pathogens in several recent studies $(2,5,13,29,31)$. This technique should soon be useful for seed health testing, and Taylor et al. (23) already have used it for the detection of Microdochium nivale in wheat seed. We showed here that rapid and specific detection of $A$. brassicae is possible using real-time PCR in the presence of SYBR green with a primer set designed from an NRPS gene sequence. This primer set gave satisfactory results with a wide range of target DNA concentrations, thus allowing accurate quantification of seed infection levels. We obtained similar $\mathrm{C}_{\mathrm{T}}$ values with DNA extracted from naturally contaminated seed (10\% infection, as estimated by the standard plating method) or from seed artificially infected with $A$. brassicae at a level of $10 \%$. Real-time PCR was found to be more sensitive than the standard amplification procedure, and a successful amplification was obtained with a seed lot with $2 \%$ A. brassicae infection. According to the Internal Seed Testing Association, this corresponds to the maximal level of infection of commercial cruciferous seed by pathogenic Alternaria spp.

The PCR diagnosis method described here, which combines DNA extraction from seed using the Nucleospin Food kit and real-time PCR in the presence of SYBR green and primers designed from an NRPS gene, is readily amenable to automation. With this method, after approximately $50 \mathrm{~h}, A$. brassicae can be accurately and sensitively detected in infected seed. Homologous sequences have been identified in the $A$. japonica and $A$. brassicicola genomes; therefore, the same method also may be applied for the detection of these two seed pathogens, provided that relevant primers are designed. Moreover, although many tests probably will be necessary to accurately correlate the amount of DNA extracted from infected seed and their level of infection (particularly when testing seed lots with very low infection levels), it should be possible to further develop this method to make it quantitative.

\section{ACKNOWLEDGMENTS}

We thank the Agence Universitaire de la Francophonie for providing B. Iacomi-Vasilescu with a post-doctoral fellowship.

\section{LITERATURE CITED}

1. Babadoost, M., Gabrielson, R. L., Olson, S. A., and Mulanax, M. W. 1993. Control of Alternaria disease of brassica seed crops caused by Alternaria brassicae and Alternaria brassicicola with ground and aerial fungicide applications. Seed Sci. Technol. 21:1-7.

2. Cullen, D. W., Lees, A. K., Toth, I. K., and Duncan, J. M. 2002. Detection of Colletotrichum coccodes from soil and potato tubers by conventional PCR and quantitative realtime PCR. Plant Pathol. 281-292.

3. De Boer, S. H., Ward, L. J., Li, X., and Chittaranjan. 1995. Attenuation of PCR inhibition in the presence of plant compounds by addition of BLOTTO. Nucleic Acids Res. 23:25672568.

4. Fernandez, D., Ouinten, M., Tantaoui, A., Geiger, J. P., Daboussi, M. J., and Langin, T. 1998. Fot 1 insertions in the Fusarium oxysporum f. sp. albedinis genome provide diagnostic PCR targets for detection of the date palm pathogen. Appl. Environ. Microbiol. 64:633-636.

5. Frederick, R. D., Snyder, K. E., Tooley, P. E., Berthier-Schaad, Y., Peterson, G. B., Bonde, M. R., Schaad, N. W., and Knorr, D. A. 2000. Identification and differentiation of Tilletia indica and $T$. walkeri using the polymerase chain reaction. Phytopathology 90:951-960.

6. Goodwin, D. C., and Lee, S. B. 1993. Microwave miniprep of total genomic DNA from fungi, plants, protists and animals for PCR. Biotechniques 15:438-444.

7. Iacomi-Vasilescu, B., Avenot, H., BatailléSimoneau, N., Laurent, E., Guénard, M., and Simoneau, P. In vitro fungicide sensitivity of Alternaria species pathogenic to crucifers and identification of Alternaria brassicicola field isolates highly resistant to both dicarboximides and phenylpyrroles. Crop Prot. In press.

8. Iacomi-Vasilescu, B., Blancard, D., Guénard, M., Molinero-Demilly, V., Laurent, E., and Simoneau, P. 2002. Development of a PCRbased diagnostic assay for detecting pathogenic Alternaria species in cruciferous seeds. Seed Sci. Technol. 30:87-95.

9. Jobes, D. V., Hurley, D. L., and Thien, L. B. 1995. Plant DNA isolation: a method to efficiently remove polyphenolics, polysaccharides, and RNA. Taxon 44:379-386.

10. Johnson, R. D., Johnson, L., Kohomoto, K., Otani, H., Lane, C; R., and Kodama, M. 2000. A Polymerase Chain Reaction-based method to specifically detect Alternaria alternata apple pathotype (A. mali), the causal agent of $A l$ ternaria blotch of apple. Phytopathology 90:973-976.

11. Joly, P. 1964. Le genre Alternaria. (The Genus Alternaria). P. Lechevalier Press, Paris.

12. Konstantinova, P., Bonants, P. J. M., Van GentPelzer, M. P. E., Van der Zouwen, P., and Van den Bulk, R. 2002. Development of specific primers for detection and identification of $\mathrm{Al}$ ternaria spp. in carrot material by PCR and comparison with blotter and plating assays. Mycol. Res. 106:23-33.

13. Lees, A. K., Cullen, D. W., Sullivan, L., and Nicolson, M. J. 2002. Development of conventional and real-time PCR assays for the detection and identification of Rhizoctonia solani AG-3 in potato in soil. Plant Pathol. 51:293302 .

14. Li, K. N., Rouse, D. I., and German, T. L.
1994. PCR primers that allow intergeneric differentiation of ascomycetes and their application to Verticillium spp. Appl. Environ. Microbiol. 60:4324-4331.

15. McKay, G. J., Brown, A. E., Bjourson, A. J., and Mercer, P. C. 1999. Molecular charaterisation of Alternaria linicola and its detection in linseed. Eur. J. Plant Pathol. 105:157-166.

16. Neegard, P. 1945. Danish Species of Alternaria and Stemphylium. Oxford University Press, London.

17. Niessen, M. L., and Vogel, R. F. 1998. Group specific PCR-detection of potential trichothecene-producing Fusarium-species in pure cultures and cereal samples. Syst. Appl. Microbiol. 21:618-631.

18. Nishimura, S., and Kohmoto, K. 1983. Hostspecific toxins and chemical structures from Alternaria species. Annu. Rev. Phytopathol 21:87-116.

19. Pryor, B. M., and Gilbertson, R. L. 2001. A PCR-based assay for detection of Alternaria radicina on carrot seed. Plant Dis. 85:18-23.

20. Rude, S. K., Duczek, L. J., and Seidle, E. 1999. The effect of Alternaria brassicae, Alternaria raphani and Alternaria alternata on seed germination of Brassica rapa canola. Seed Sci. Technol. 27:795-798.

21. Shrestha, S. K., Mathur, S. B., and Munk, L. 2000. Alternaria brassicae in seeds of rapeseed and mustard, its location, transmission from seeds to seedling and control. Seed Sci. Technol. 28:75-84.

22. Smith, O. P., Peterson, G. L., Beck, R. J Schaad, N. W., and Bonde, M. R. 1996. Development of a PCR-based method for identification of Tilletia indica, causal agent of Karnal bunt of wheat. Phytopathology 86:115-122.

23. Taylor, E., Bates, J., Kenyon, D., Maccaferri, M., and Thomas, J. 2001. Modern molecular methods for characterization and diagnosis of seed-borne fungal pathogens. J. Plant Pathol. 83:75-81

24. Taylor, J. L. 1993. A simple, sensitive, and rapid method for detecting seed contaminated with highly virulent Leptosphaeria maculans. Appl. Environ. Microbiol. 59:3681-3685.

25. Tewari, J. P. 1991. Structural and biochemical bases of the blackspot disease of crucifers. Adv. Struct. Biol. 1:325-349.

26. Verma, P. R., and Saharan, G. S. 1994. Monograph of Alternaria diseases of Crucifers. In: Saskatoon Research Centre Technical Bulletin 1994-6E. Agriculture and Agri-Food Canada, Saskatoon, SK, Canada.

27. Walton, J. D. 1996. Host-selective toxins: Agents of compatibility. Plant Cell 8:17231733.

28. White, T. J., Bruns, T., Lee, S., and Taylor, J. 1990. Amplification and direct sequencing of fungal ribosomal genes for phylogenetics. In: PCR protocols: A guide to methods and applications. Academic Press. San Diego, CA.

29. Winton, L. M., Stone, J. K., Watrud, L. S., and Hansen, E. M. 2002. Simultaneous one-tube quantification of host and pathogen DNA with real-time polymerase chain reaction. Phytopathology 92:112-116.

30. Wu, W. S., and Chen, T. W. 1999. Development of a new selective medium for detecting Alternaria brassicicola in cruciferous seeds. Seed Sci. Technol. 27:397-409.

31. Zhang, A. W., Hartman, G. L., Curio-Penny, B., and Becker, K. B. 1999. Molecular detection of Diaporthe phaseolorum and Phomopsis longicolla from soybean seeds. Phytopathology 89:796-804.

32. Zur, G., Hallerman, E. M., Sharf, R., and Kashi, Y. 1999. Development of a Polymerase Chain Reaction-based assay for the detection of Alternaria fungal contamination in food products. J. Food Prot. 62:1191-1197. 